\title{
Acute Rheumatic Fever Cases Presented with Enthesitis: A Different View on Acute Rheumatic Fever
}

\author{
Entezit ile Prezente Olan Akut Romatizmal Ateş Olguları: \\ Akut Romatizmal Ateşe Farklı Bir Bakış

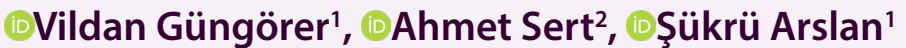 \\ 'Selcuk University School of Medicine Department of Pediatrics, Division of Pediatric Rheumatology \\ ${ }^{2}$ Selcuk University School of Medicine Department of Pediatrics, Division of Pediatric Cardiology, Konya, Turkey
}

\section{ABSTRACT}

\begin{abstract}
Aim: Acute rheumatic fever (ARF) is a non-suppurative inflammatory disease that develops after group A Beta hemolytic streptococcal pharyngitis, primarily involving the heart, joint, central nervous system, skin and subcutaneous tissue. Today, Jones criteria; that were modified in 2015, are used for diagnosis. Our aim in this study is to examine the patients diagnosed with acute rheumatic fever in our clinic and presented with enthesitis.
\end{abstract}

Material and Method: The type of study is case report. Five patients who were admitted to the Pediatric Rheumatology Clinic of Selçuk University Faculty of Medicine were diagnosed with acute rheumatic fever and presented with enthesitis, between 2017- 2019 were examined retrospectively. Their demographic, clinical laboratory and echocardiographic data were examined. The presence of enthesitis in all patients was established with one or more of the options of clinical examination, ultrasonography, magnetic resonance imaging, and/or orthopedics opinion.

Results: While the clinic of the patients improved with the treatment for enthesitis, acute phase reactants did not fall and additional clinical findings appeared. Our observations suggested that acute rheumatic fever could apply to us not only with arthritis and arthralgia, but also with the enthesitis clinic. Therefore, we think that if the laboratory data are compatible among the differential diagnoses in patients presenting with enthesitis, acute rheumatic fever should also be considered, and careful physical examination and echocardiography should be performed for this purpose.

Conclusion: In relation to the pathogenesis of the rheumatological diseases, new clinical situations are emerging day by day, and in this way, the diseases are better understood and classified. In conclusion, we think that ARF can be encountered not only with arthritis and arthralgia but also with enthesitis clinics, and echocardiographic imaging should not be ignored in patients with enthesitis clinic who have high acute phase reactants and who do not meet the enthesitis-related juvenile idiopathic arthritis criteria.

Keywords: Acute rheumatic fever, arthralgia, arthritis, carditis, enthesitis

\section{ÖZ}

Amaç: Akut romatizmal ateş (ARA) A grubu Beta hemolitik streptokok (GAS) farenjitinden sonra gelişen, süpüratif olmayan, başlıca kalp, eklem, santral sinir sistemi, deri ve deri altı dokusunu tutan enflamatuvar bir hastalıktır. Tanı için günümüzde 2015 yılında modifiye edilen Jones kriterleri kullanılmaktadır. Bu çalışmadaki amacımız kliniğimizde izlediğimiz ARA tanısı almış ve entezit ile prezente olan hastaları değerlendirmektir.

Gereç ve Yöntem: Selçuk Üniversitesi Tıp Fakültesi Çocuk Romatoloji kliniğine 2017- 2019 yılları arasında entezit kliniği ile başvurup akut romatizmal ateş tanısı konulmuş olan 5 hasta retrospektif olarak incelendi. Tüm hastalarda ARA tanısı öncesi entezit tanısı konularak tedavisi verildi. Hastaların demografik, klinik, laboratuvar ve ekokardiyografik verileri incelendi. Entezit varlığı fizik muayene, ultrasonografi, manyetik rezonans görüntüleme ve/veya Ortopedi hekiminin kararı seçeneklerinin biri veya birden fazlası seçenekleri ile konuldu.

Bulgular: Entezite yönelik tedavi ile hastaların kliniği düzelirken akut faz reaktanlarının düşmedi ve ek klinik bulgular ortaya çıtı. Sonuç olarak gözlemimiz akut romatizmal ateşin sadece artrit ve artralji değil entezit kliniği ile de tarafımıza başvurabileceğidir.

Sonuç: Romatolojik hastalıklarda hastalıkların patogeneziyle ilgili olarak her geçen gün yeni klinik durumlar ortaya çıkmakta ve bu şekilde hastalıkların daha iyi anlaşılıp sınıflanması sağlanmaktadır. Sonuç olarak gözlemimiz ARA' nın sadece artrit ve artralji değil entezit kliniği ile de karşımıza çıkabileceğini, entezit kliniği olup akut faz reaktanları yüksek olan ve entezit ilişkili juvenil idiyopatik artrit kriterlerini karşılamayan hastalarda ekokardiyografik görüntülemenin göz ardı edilmemesi gerektiğini düşünmekteyiz.

Anahtar Kelimeler: Akut romatizmal ateş, artrit, entezit, kardit 


\section{INTRODUCTION}

Acute rheumatic fever (ARF) is a non-suppurative inflammatory connective tissue disease that develops after group (interm) A Beta hemolytic streptococcal (GAS) pharyngitis, primarily involving the heart, joint, central nervous system, skin and subcutaneous tissue. ARF is the most important cause of acquired heart diseases in children and young adults, particularly, in developing countries. The main factor that affects the morbidity and mortality of the disease is the involvement of the heart (1).

In the world, every year, 470,000 new cases of rheumatic carditis of all ages are detected and, about 340,000 of these occur in children aged 5-14. For this reason, ARF remains clinically important although the incidence of ARF in developed countries decreases. $(2,3,4,5,6)$.

The most commonly seen age of the disease is between 5 and 15 years $(7,8,9)$. ARF diagnosis is made based on clinical and laboratory findings. Although the clinic of acute rheumatic fever dates back to very old times, the first criteria for diagnosis were defined by Jones and these criteria have been modified several times over time. Today, Jones criteria, that were modified in 2015, are used for diagnosis (10). A new update has not been made on this after 2015. No new clinical observations have been reported over time.

Entheses are sites of attachment of tendons, ligaments, fasciae, and articular capsules to bones. Enthesitis is characterised by pain and stiffness at tendon insertions, such as the achilles tendon, the plantar fascia or the common extensor tendon insertion at the epicondyle of the elbow. Clinical assessment of enthesitis has been based traditionally by recognition of tenderness elicited by the palpation of the entheseal site. In recent years, enthesitis can be evaluated more objectively with ultrasonography and magnetic resonance imaging. Enthesitis is common in some forms of arthritis, including psoriatic arthritis and ankylosing spondylitis. In addition, rheumatoid arthritis and inflammatory bowel disease have also been associated with enthesitis (11). As the pathophysiology that causes enthesitis is understood, as clinical experience increases and the importance given to the enthesitis clinic increases, we think that we will see that it accompanies many other diseases.

Our purpose in this study is to examine the demographic, clinical and laboratory data of 5 patients diagnosed with ARF and presented with enthesitis whom we followed in our clinic and to show that ARF can also be presented with enthesitis in the light of these patients and, to shed light on the different clinical presentation we observed in the ARF diagnostic criteria, which will be updated again in the coming years.

\section{MATERIAL AND METHOD}

In this study, 5 patients younger than 18 years old who were admitted to the Pediatric Rheumatology Outpatient Clinic of Selçuk University Faculty of Medicine were diagnosed with ARF between 2017- 2019 and were examined retrospectively.

The patients were diagnosed according to the modified Jones 2015 criteria. According to these criteria, arthritis, carditis, erythema marginatum, subcutaneous nodule and chorea were major criteria, while fever, arthralgia, increase in C-reactive protein and sedimentation, and prolongation of PR interval in electrocardiography were minor criteria. Since our country is in the middle or high risk group, whereas polyarthralgia and monoarthritis are among the major criteria, fever above 38 degrees and sedimentation> $30 \mathrm{~mm} /$ hour are considered as minor criteria (10).

The presence of enthesitis in all patients was established with one or more of the options of clinical, examination, ultrasonography, magnetic resonance imaging, and/ or orthopedics opinion. All patients underwent echocardiography in terms of cardiac involvement in the Department of Pediatric Cardiology. Informed consent was obtained from the patients that their data would be used. Patients' data were accessed from the patient files and via the computer information system.

\section{Ethics Committee Approval}

The study was conducted in accordance with the Helsinki Declaration principles. The study was approved by the Clinical Research Ethics Committee of Selçuk University (Date: 30.12.2020, Protocol no: 2020/581).

\section{Statistical Analysis}

All data were analyzed using the SPSS 21.0 software. While evaluating the study data, mean, standard deviation, median, frequency, ratio, minimum, and maximum were used for descriptive statistics.

\section{RESULTS}

\section{Case 1}

A 10-year-old female patient applied with the complaint of a pain covering whole leg for $4-5$ months, pain in the wrists and not being able to step on her heels which developed in the last 1 week. There was no history of infection or trauma prior to the complaints. Physical examination revealed sensitivity, redness and slight temperature increase at the heel and enthesis points at underfoot but there was no swelling. In laboratory investigations, C-reactive protein (CRP):23 mg/L, Anti-streptolysin-O (ASO): 544 IU/ $\mathrm{ml}$ and erythrocyte sedimentation rate (ESR):56 mm/h, Hemoglobin (Hb): $11.3 \mathrm{~g} / \mathrm{dl}$, white blood cells (Wbc): 5700 K/uL, neutrophiles: $3020 \mathrm{~K} / \mathrm{uL}$, platelets (Plt): $468000 \mathrm{~K} /$ 
uL. Patient, who was considered to have plantar fasciitis, was consulted to the Orthopedics and Traumatology Department in this regard. Patient, who was considered to have plantar fasciitis by the Department of Orthopedics and Traumatology, was started with cold application, resting and nonsteroidal anti-inflammatory (NSAI) therapy. When the complaints of the patient did not improve, other investigations were carried out on etiology. There was no family history of rheumatological disease. Brucella and viral serology were normal. Echocardiography $(\mathrm{ECHO})$ revealed minimal central mitral insufficiency (MI) with central jet and minimal aortic insufficiency (AI) with a length of $7 \mathrm{~mm}$. During this period, the patient who received NSAI treatment started to step on her feet. The pain she described in the wrists and the entire leg was alleviated. In control echocardiography, 1 week later, 2.2 $\mathrm{mm}$ minimal $\mathrm{Al}$ and minimal Ml were detected, with an increase in central jet thickness compared to the previous one. It was diagnosed with ARF carditis with polyarthralgia, endocarditis, increased acute phase reactant and ASO. Prednisolone treatment at a dose of $2 \mathrm{mg} / \mathrm{kg} /$ day and depociline prophylaxis were started. The patient's complaints and laboratory investigations were completely recovered. Under penicillin prophylaxis, the patient had no complaints and normal physical examination findings at the control 6 months later.

\section{Case 2}

A 8-year-old male patient had a history of antibiotic use due to fever and cough. He has described pain in the ankle and foot metatarsal joints for the last 3 days. Patient had a fever of $38.4^{\circ} \mathrm{C}$. There was an increase in sensitivity and temperature in the areas that match to the sole of the tarsometatarsal joints but there was no swelling or redness. He had difficulty in standing on his feet. There was also sensitivity in the costochondral junction regions. The patient was thought to have costochondritis and plantar fasciitis and was given NSAID, but he was referred to us because of high AFR. The results of laboratory analysis of blood samples were as follows: Wbc: $11600 \mathrm{~K} /$ uL, neutrophile:7150 K/uL, Hb:12,7 g/dL, Plt: $474000 \mathrm{~K} /$ uL, ASO:873 IU/ml CRP:29.2 mg/L ESR: 47 mm/h, Brucella serology negative. With NSAID therapy the patient's complaints quickly relieved but acute phase reactants did not decrease. Therefore, we evaluated the patient in terms of other etiologies. There was no family history of rheumatological disease. The HLA B27 gene was negative. There was no inflammatory back pain and sacroiliac tenderness. Electrocardiogram and $\mathrm{ECHO}$ were performed to the patient for differential diagnosis. PR interval was $0,16 \mathrm{sec}$ and $2.6 \mathrm{~mm}$ central jet thickness, 1 st Degree Al and trace $\mathrm{Ml}$ were detected in ECHO. The patient was diagnosed with ARF with fever, ECHO findings, and increased acute phase reactants. Prednisolone therapy ( $2 \mathrm{mg} / \mathrm{kg} /$ day) was started with deposiciline prophylaxis. After treatment the patient was completely recovered.

\section{Case 3}

A 9-year-old girl had a history of antibiotic use which she did not know the name, because of tonsilitis 15 days before admission. The patient admitted with the complaint of pain when stepped on her left soles. Skin lesions were observed the patient on chest front face and back which had hyperemic edges pale middle region. The lesions were fading when pressed on them. Cardiac auscultation murmur was present in 2/6 degrees. There were sensitivity, slight redness and an increase in temperature in the area that match to the left metatarsal joints when pressed from the sole of the foot. In the superficial ultrasonography (USG) of the foot, thickening of the plantar fascia, inflammation and mild bone marrow edema were observed especially in the area where the plantar fascia adhered to the metatarsal and calcaneus. In his laboratory investigations Wbc:9800 K/uL, neutrophiles:5790 K/uL, Hb:10,6 g/dL, Plt:336000 $\mathrm{K} / \mathrm{uL}$, ASO:726 IU/ml CRP:75 $\mathrm{mg} / \mathrm{L}$ ESR:32 mm/h, Brucella serology was negative. PR was determined as prolonged by $0.18 \mathrm{sec}$ in electrocardiography when evaluated by age. ARF carditis was considered in the patient where there is central jet $6 \mathrm{~mm}$ minimal $\mathrm{MI}$ and 1 st degree tricuspid regurgitation (TR) in ECHO. The rashes were evaluated as erythema marginatum after taking the opinion of the dermatology. The patient was diagnosed with ARF with the findings of erythema marginatum, carditis and increased acute phase reactants. Prednisolone treatment and depociline prophylaxis were started. There was no apparent TR, MI in control ECHO six months later.

\section{Case 4}

A 15-year-old male patient with a history of febrile upper respiratory infection 1 month ago had a complaint of sensitivity at first right then left foot heel when stepping on with mild swelling. Also there was pain in the knee and ankles joint for the last 2 weeks. The patient's outer center magnetic resonance imaging (MRI) was compatible with plantar fasciitis. With the diagnosis of plantar fasciitis, the patient was recommended cold administration and NSAI treatment by the Orthopedics and Traumatology Department. The patient, who was temporarily relieved after cold application and medication, applied to us after the continuation of her complaints. There was a 2 nd degree cardiac murmur by auscultation in the physical examination of the patient who had normal vital signs. The left calcaneus and achilles tendon was sensitive with palpation and there was slight swelling compared to right. As a result of investigations; Wbc: $12900 \mathrm{~K} / \mathrm{uL}$, neutrophils: $9200 \mathrm{~K} / \mathrm{uL}, \mathrm{Hb}: 13.5 \mathrm{~g} / \mathrm{dL}$ Platelets: 366000 K / uL, CRP: 48 mg / L, ESR: 33 mm / s, ASO: 303 IU / ml, Brucella serology negative, HLAB27 negative, PR interval $0.18 \mathrm{sec}$, at ECHO: 1st Degree MI detected. The patient who had polyarthralgia and carditis was diagnosed with ARF and prednisolone treatment was given. 


\section{Case 5}

11-year-old girl applied to us with complaints of localized swelling, temperature increase and pain on the left knee for the last 3 days. It was learned from the history that the patient had a throat infection 20 days ago and was treated with amoxicillin clavulanic acid. She had a wandering arthralgia in the elbows, knees and ankles for 2 weeks. Localized swelling, tenderness and temperature increase on the tuberositas tibia and 1 st degree murmur were detected in the physical examination of the patient, whose vital signs were stable. In her examinations, Wbc:10600 K/uL, neutrophile:7000 $\mathrm{K} / \mathrm{uL}, \mathrm{Hb}: 12.5 \mathrm{~g} / \mathrm{dL}$ Platelets:326000 K/uL, ASO:1270 IU/mL, CRP:37.4 mg/L ESR:77 mm/h, Brucella serology and HLA B27 were negative. Minimal $\mathrm{Al}$ and $\mathrm{Ml}$ were observed in the ECHO of the patient whose PR interval was 0.16 sec.on electrocardiography and control ECHO was recommended. The orthopedics and traumatology department was consulted with x-rays taken on the knee and ankle, and the patient was thought to have enthesitis in the adhesion areas of the patella and achilles tendon. Cold application and resting were recommended to the patient. The PR interval extended to $0.24 \mathrm{~s}$ in the followup of the patient, whose enthesitis findings improved with these treatments. In Control ECHO, 1st degree trace $\mathrm{MI}$ and $\mathrm{Al}$ were detected. Deltacortril and depociline prophylaxis was started in the patient who was evaluated as ARF carditis.

Demographic and clinical features of the patients are summarized in Table $\mathbf{1}$ and laboratory findings are summarized in Table 2.

\section{DISCUSSSION}

Acute rheumatic fever is an autoimmune disease with multisystemic involvement observed after tonsillopharyngitis caused by infection of streptococcus pyogenes. It still makes up a large part of acquired heart diseases in underdeveloped and developing countries (12).

Although the frequency of ARF has been decreasing in the last 20 years as living conditions have improved gradually and more planned and since there are controlled practices, treatments and prophylaxis on health related issues in developed countries, ARF remains to be important with the cardiac sequels it left in underdeveloped and developing countries (13). The regions where rheumatic fever is seen most frequently are African countries, Brazil, Central-South Asian regions that are in the south of Sahara desert. Frequency of ARF in school-age children is $\leq 2 / 100,000$, and communities that are with a prevalence of rheumatic heart disease $\leq 1$ / 1000 at all ages are defined as are low risk; others are defined as moderate and high risk (14). While frequency of ARF increased regionally during epidemic periods, incidence of ARF decreased in the developed countries starting with 2000s. The incidence in Canada, the USA and Western Europe varies between 0.1-2/100,000 (15). In the latest studies carried out in the Central Anatolia region in Turkey ARF-incidence between the ages of 1014 has been found to be 7.4/100,000 (16). Our country, that has similar results from other regions, falls into the middle and high-risk communities in terms of ARF frequency according to these data.

\begin{tabular}{|c|c|c|c|c|c|c|c|c|c|c|c|}
\hline $\begin{array}{l}\text { Patient's } \\
\text { no }\end{array}$ & $\begin{array}{l}\text { Gender } \\
\text { (M/F) }\end{array}$ & $\begin{array}{c}\text { Age } \\
\text { (year) }\end{array}$ & Arthritis & Arthralgia & Entesitis & $\begin{array}{c}\text { Cardiac } \\
\text { Involvement }\end{array}$ & $\begin{array}{c}\text { Eritema } \\
\text { marginatum }\end{array}$ & Fever & $\begin{array}{l}\text { Subcutaneous } \\
\text { nodule }\end{array}$ & $\begin{array}{c}\text { Duration at } \\
\text { hospitalization }\end{array}$ & $\begin{array}{l}\text { Previous } \\
\text { enfectious }\end{array}$ \\
\hline 1 & $\mathrm{~F}$ & 10.7 & - & + & + & + & - & - & - & 2 week & None \\
\hline 2 & M & 8.6 & - & + & + & + & - & + & - & 2 week & 1 week ago \\
\hline 3 & $\mathrm{~F}$ & 9 & - & + & + & + & + & - & - & 2 week & 15 days ago \\
\hline 4 & M & 15 & - & + & + & + & - & - & - & 2 week & 30 days ago \\
\hline 5 & $\mathrm{~F}$ & 11.9 & - & + & + & + & - & - & - & 2 week & 20 days ago \\
\hline
\end{tabular}

Table 2: Laboratory and Imaging Results of Patients

\begin{tabular}{|c|c|c|c|c|c|c|c|c|}
\hline Patient & $\begin{array}{l}\text { PR } \\
\text { (sc) }\end{array}$ & $\begin{array}{c}\text { CRP } \\
(\mathrm{mg} / \mathrm{L})\end{array}$ & $\begin{array}{l}\text { Sedimantation } \\
\text { (mm/hour) }\end{array}$ & $\begin{array}{c}\text { ASO } \\
(I \mathrm{IU} / \mathrm{ml})\end{array}$ & $\begin{array}{l}\text { Wbc } \\
\text { (K/ul) }\end{array}$ & $\begin{array}{c}\text { Neutrophil } \\
\text { (K/ul) }\end{array}$ & Echocardiography & $\begin{array}{l}\text { Brucella } \\
\text { serology }\end{array}$ \\
\hline 1 & 0.12 & 23 & 56 & 544 & 5700 & 3020 & Minimal MI, minimal Al & negative \\
\hline 2 & 0.16 & 29.2 & 47 & 873 & 11600 & 7150 & $1^{\text {st }}$ degree $\mathrm{Al}$, trace $\mathrm{MI}$ & negative \\
\hline 3 & 0.18 & 75 & 32 & 726 & 9800 & 5790 & $1^{\text {st }}$ degree $\mathrm{Ml}, 1^{\text {st }}$ degree TR & negative \\
\hline 4 & 0.18 & 48 & 33 & 303 & 12900 & 9200 & $1^{\text {st }}$ degree $\mathrm{MI}$ & negative \\
\hline 5 & 0.24 & 37 & 77 & 1270 & 10600 & 7000 & $1^{\text {st }}$ degree $\mathrm{MI}$, minimal $\mathrm{Al}$ & negative \\
\hline
\end{tabular}


Although the ARF clinic has been known since 1500s, the relationship of the heart with ARF has been defined as from tonsilitis to carditis in the 18th century, and in 1884 Laseque used the expression that ARF licks the joints and bites the heart (17). Criteria has been created by Jones in 1944 and were last updated in 2015 (10). In the 2015 update, societies were divided into two as low-risk and mediumhigh-risk, accordingly, polyarthralgia and monoarthritis were included in the major criteria in medium and high-risk societies, whereas erythrocyte sedimentation rate above 30 and fever above 38 degrees were also changed to be minor criteria. According to the latest Jones update, Turkey is among the medium and high-risk populations in terms of ARF frequency (14). After the 2015 Jones criteria updated considering the ARF frequency and clinical observations, no new announcement or updates related to ARF clinics were made. 5 of the ARF patients diagnosed between 2018-2020 by our clinic have initially applied to us with the enthesitis findings and, since this enthesitis is confirmed using USG or MRI by consultation with Orthopedics and Traumatology Department this clinical situation made us think that ARF can also be presented with enthesitis. Although there are no cases in the literature review on this subject, we think that ARF cases presented with new enthesitis after this article will be identified and perhaps this finding will gain value in the future.

Acute rheumatic fever involves heart, joints, brain, subcutaneous connective tissue and blood vessels, but permanent sequela depends on cardiac involvement only. It is mostly seen in temperate regions, regardless of gender and race, in spring and winter seasons (4). The cause of the disease is GAS, but the mechanisms by which streptococci cause the disease have not yet been elucidated. GAS are also called "streptococcus piyogenes" and make up the majority of bacterial infections in childhood (18). The most emphasized assumption in pathogenesis is the crossreaction theory. Since some streptococcal antigens are similar to tissue antigens, clinical findings are thought to occur with the stimulation of the cellular and humoral immune system $(19,20)$. However, the cross-response theory could not clearly explain why we are able to prevent ARF when treatment is given in the first 9 days.

Clinical findings in ARF begin to appear after 2-5 weeks of latent period after GAS infection and tonsillitis. The main clinical findings are wandering polyarthritis, carditis, chorea, erythema marginatum and subcutaneous nodules $(4,18,21,22)$. Erythema marginatum is a skin lesion that is pale in the middle with edges having hyperemic painless macular feature and, is often difficult to catch because they occur for a very short time. The incidence is around $5 \%$ and it is more common in patients with carditis (18, 23). The subcutaneous nodule is also observed around 5\%, and it is a hard, painless, mobile, approximately $0.5-1 \mathrm{~cm}$ diameter nodules that can be found in the extensor faces of the extremities, above the spinous protrusions of the vertebrae and in the occiput $(18,21)$. Korea, also known as Sydenham chorea, is a late finding of acute rheumatic fever and it is characterized by leaping movements in a way of involuntary dances. Particularly, deterioration in fine motor movements and inappropriate mood impairment are at the forefront (18).

Carditis occurs in $45-50 \%$ of patients and it is the main factor that determines the course of the disease and sequel formation. It can involve all layers of the heart. Endocardial involvement is the most common, involvement of other heart layers occurs after endocardial involvement (23). Most frequently involved valve is the mitral valve. Echocardiographically, valve insufficiency can be detected in a significant amount of patients who applied with arthritis and chorea and who do not have carditis and murmur in their clinic. This condition is called "silent carditis" and it was found that $12-21 \%$ of children with ARF developed silent carditis (24).

Arthritis is the most common finding in ARF, and it is seen in $75-80 \%$ of patients. Typically, more than one, wandering and large joint involvement is seen. Unusual cases such as small joint involvement and sacroiliac joint involvement have also been reported in recent years (25).

Minor findings of ARF are fever, arthralgia, increased acute phase reactants and prolonged PR interval in electrocardiography. If there is arthritis, arthralgia and PR prolongation are not considered as minor criteria (23). In addition, coronary artery involvement, pericarditis leading to tamponade, advanced atrioventricular (AV) blocks, in association with acute appendicitis, acute glomerulonephritis in association with ARF, Henoch Schönlein Purpura (HSP) in association with ARF have been reported $(26,27,28,29,30,31,32)$. In our cases, unlike the cases previously reported in the literature, patients applied to the enthesitis clinic, but patients were diagnosed with ARF after physical examination and laboratory examinations.

\section{CONCLUSION}

As a result, when the literature was reviewed, ARF is a multi-systemic inflammatory disease and over time, the diagnostic criteria have undergone many modifications based on clinical and laboratory observations. In relation to the pathogenesis of the rheumatological diseases, new clinical situations are emerging day by day, and we see both that the diseases are better understood and classified and more accurate treatment options are developed. Our purpose in this study is to share the different clinical presentation we observed in the ARF and to shed light on the different clinical presentations. We believe that the ARF diagnosis in patients presenting with enthesitis should also be held in the corner of our minds and careful differential diagnosis should be made in consideration with other clinical and laboratory findings. 


\section{ETHICAL DECLARATIONS}

Ethics Committee Approval: The study was approved by the Clinical Research Ethics Committee of Selçuk University (Date: 30.12.2020, Protocol no: 2020/581).

Informed Consent: Because the study was designed retrospectively, no written informed consent form was obtained from patients.

Referee Evaluation Process: Externally peer-reviewed.

Conflict of Interest Statement: The authors have no conflicts of interest to declare.

Financial Disclosure: The authors declared that this study has received no financial support.

Author Contributions: All of the authors declare that they have all participated in the design, execution, and analysis of the paper, and that they have approved the final version.

Acknowledgement: The authors thank Enago https://www.enago.com.tr/ceviri/ for their assistance in manuscript translation and editing.

\section{REFERENCES}

1. Tani LY. Rheumatic fever and rheumatic heart disease. In:Allen HD, Driscoll MD, Shaddy RE, Feltes TF, (eds). Moss and Adams Heart Disease in Infants, Children, and Adolescents. 8th ed. Philadelphia, PA:Lippincott Williams \&Wilkins, 2013:1303-30.

2. Barash Y, Matityahu A. Acute rheumatic fever. Isr J Fam Pract 2005;15:7-13.

3. Carapetis JR, Currie BJ, Mathews JD. Cumulative incidence of rheumatic fever in an endemic region:a guide to the susceptibility of the population? Epidemiol Infect 2000;124:239-44.

4. Carapetis JR, McDonald M, Wilson NJ. Acute rheumatic fever. Lancet 2005;366:155-68.

5. Guidelines for the diagnosis of rheumatic fever. Jones Criteria update. Special Writing Group of the Committee on Rheumatic Fever, Endocarditis, and Kawasaki Disease of the Council on Cardiovascular Disease in the Young of the American Heart Association. JAMA 1992;268:2069-73.

6. World Health Organization. Strategy for controlling rheumatic fever/rheumatic heart disease, with emphasis on primary prevention:memorandum from a joint WHO/ISFC meeting. Bull World Health Organ 1995;73:583-7.

7. Carapetis JR, Brown A, MAguire G, Walsh W, Noonan S, Thompson $D$. The Australian guideline for prevention, diagnosis and management of acute rheumatic fever and rheumatic heart disease. 2nd ed. Sydney:Heart Foundation and Cardiac Society of Australia and New Zealand, 2012.

8. Tani LY, Veasy G, Minich L, Shaddy RE. Rheumatic fever in children younger than 5 years:Is the presentation different? Pediatrics 2003;112:1065-8.

9. Wang C, Liu C, Li Y, Liu M. Adult onset acute rheumatic fever Possible resurgence in southern Taiwan. J Clin Rheumatol 2005;11:146-9.

10. Gewitz MH, Baltimore RS, Tani LY, et al. Revision of the Jones criteria for the diagnosis of the rheumatic fever in the era of Doppler echocardiography:A scientific statement of the American Heart Association. Circulation 2015;131:1806-18.

11. Husic R, Lackner A, Kump PK, Högenauer C, GraningerW, Dejaco C High Prevalence of Ultrasound Verified Enthesitis in Patients With Inflammatory Bowel Disease With or Without Spondylarthritis. Frontiers in Medicine. 2021;8

12. Tibazarwa K, Volmink J, Mayosi B. Incidence of acute rheumatic fever in the world:a systematic review of population-based studies. Heart 2008;94:1534-40.
13. Köksal AO, Gültekin Soylu A, Özdemir O. Akut Romatizmal Ateş. Turkish J Pediatr Dis 2016;4:283-96.

14. Orün UA, Ceylan O, Bilici $M$, et al. Acute rheumatic fever in the Central Anatolia Region of Turkey:a 30-year experience in a single center. Eur J Pediatr 2012;171:361-8.

15. Madden S, Kelly L. Update on acute rheumatic fever;it stil exists in remote communities. Can Fam Physician 2009;55:475-8.

16. Narin N, Mutlu F, Argun $M$, et al. Incidence and clinical features of acute rheumatic fever in Kayseri, Central Anatolia 1998-2011. Cardiol Young 2015;25:745-51.

17. Dajani AS, Ayooub E, Bierman FZ, et al. Special Writing Group of the Committee on Rheumatic Fever, Endocarditis and Kawasaki Disease of the Council on Cardiovascular Disease in the Young the American Heart Association. Guidelines for the diagnosis of rheumatic fever. Jones criteria, 1992 update. JAMA 1992;268:2069-73.

18. Galal ME, Medhat ME, Khalid AS, Howaida GE. Rheumatic fever and rheumatic heart disease. In:The Science and practice of Pediatric Cardiology. Garson A, Bricker JT, Fisher DJ, Neish SR (eds). 2nd ed. Baltimore:Williams and Wilkins, 1998:1691-24.

19. Fae KC, Oshiro SE, Toubert A, Charron D, Kalil J, Guilherme L. How an autoimmune reaction triggered by molecular mimicry between streptococcal $M$ protein and cardiac tissue proteins leads to heart lesions in rheumatic heart disease. J Autoimmun 2005;24:101-9.

20. Akalın, Figen. "Novelties in acute rheumatic fever." Turkish Archives of Pediatrics 2007;42.3:85-93.

21. Writing group of the committee on rheumatic fever, endocarditis, and Kawasaki Disease of the council on cardiovascular disease in the young of the American Heart Association. Guidelines for the diagnosis of acute rheumatic fever. Jones criteria 1992 update. JAMA 1992;268:2069-73.

22. Ferreri P. Proceedings of the Jones criteria workshop. Circulation 2002;106:2521-3.

23. Narula J, Chandrasekhar Y, Rahimtoola S. Diagnosis of active rheumatic carditis. The echoes of change. Circulation 1999;100:1576-81.

24. Tubridy-Clark M, Carapetis JR. Subclinical carditis in rheumatic fever:a systematic review. Int J Cardiol 2007;119:54-8.

25. Olgunturk R, Canter B, Tunao.lu FS, Kula S. Review of 609 patients with rheumatic fever in terms of revised and updated Jones criteria. Int J Cardiol 2006;112:91-8.

26. Turley AJ, McCarron B, de Belder MA. Acute rheumatic fever mimicking acute coronary syndrome. Emerg Med J 2006;23:e45.

27. Gunal N, Baysal K, Hacıomeroğlu P, Belet N, Kolbakır F. Rheumatic fever and coronary vasculitis in children. Acta Paediatr 2006;95:118-20.

28. Unal N, Kosecik M, Saylam GS, Kır M, Paytoncu S, Kumtepe S. Cardiac tamponade in acute rheumatic fever. Int J Cardiol 2005; 103:217-8

29. Mohindra R, Pannu HS, Mohan B, et al. Syncope in a middle aged male due to acute rheumatic fever. Indian Heart J 2004;56:668-9.

30. Kula S, Olgunturk R, Ozdemir O. Two unusual presentations of acute rheumatic fever. Cardiol Young 2005;15:514-6.

31. Kula S, Saygılı A, Tunao.lu FS, Olgunturk R. Acute poststreptococcal glomerulonephritis and rheumatic fever in the same patient:a case report and review of the literature. Anadolu Kardiyol Derg 2003;3:272-4.

32. Ei-Menyar A, Ai-Hroob A, Numan MT, Gendi SM, Fawzy IM Unilateral pulmonary edema:unusual presentation of acute rheumatic fever. Pediatr Cardiol 2005;26:700-2. 